\title{
The relationships among impulsivity, anxiety sensitivity, and severity of social anxiety disorder
}

\author{
Dürtüsellik ve anksiyete duyarliliği özelliklerinin sosyal anksiyete \\ bozukluğu'nun şiddeti ile ilişkisi \\ Safiye Bahar Ölmez ${ }^{1}$,Ahmet Ataoğlu² \\ ${ }^{1}$ M.D., Department of Psychiatry, Düzce University School of Medicine, Düzce, Turkey https://orcid.org/0000-0003-4793-7514 \\ 2Prof., Department of Psychiatry, Düzce University School of Medicine, Düzce, Turkey https://orcid.org/0000-0002-6435-1286
}

\begin{abstract}
SUMMARY
Objective: The purpose of this study is to examine the characteristics of impulsivity and anxiety sensitivity in patients with Social Anxiety Disorder (SAD) and to investigate relationships between these characteristics and the severity of SAD. Method: The sample consisted of outpatients $(n=42)$ who had been diagnosed with only SAD based on the American Psychiatric Association's Diagnostic and Statistical Manual of Mental Disorder, in addition to healthy individuals $(n=51)$ serving as the control group. Data collection tools were the sociodemographic form, the Barratt Impulsivity Scale (BIS-11), the Anxiety Sensitivity Index (ASI-3), and Liebowitz Social Anxiety Scale (LSAS). Results: The mean total score of the BIS-11 in the SAD group was found to be significantly higher than the mean total BIS-11 score in the control group ( $p<0.001)$. Compared to the mean total ASI-3 score, the SAD group's mean score was significantly higher than the control groups mean scores ( $p$ $<0.001$ ). The analysis of variance revealed that the cognitive and social dimensions and total ASI-3 scores were positively correlated with total LSAS scores $(r=0.434$, $r=0.427$, and $r=0.351$, respectively). Additionally, there was a negative correlation between the attention impulsivity subscore and the LSAS avoidance subscore ( $r=-$ 0.353). Discussion: Patients with SAD have more impulsivity and anxiety sensitivity characteristics than healthy individuals. Moreover, anxiety sensitivity and attention impulsivity characteristics of patients with SAD are associated with symptom severity.
\end{abstract}

Key Words: Anxiety sensitivity, Liebowitz Social Phobia Anxiety Scale, impulsivity, social anxiety disorder
ÖZET

Amaç: Bu çalışmanın amacı Sosyal Anksiyete Bozukluğu (SAB) hastalarında dürtüselik ve anksiyete duyarlılığı özelliklerinin incelenmesi ve bu özelliklerin $S A B^{\prime}$ nın şiddeti ile ilişkisinin araştırılmasıdır. Yöntem: Çalışmanın örneklemini Amerikan Psikiyatri Birliği Mental Hastalıkların Tanı ve Sınıflandırması Kılavuzunun beşinci versiyonuna göre tanı almış $42 \mathrm{SAB}$ hastasından oluşan SAB grubu ve psikiyatrik tanısı bulunmayan 51 sağlıklı bireyden oluşmuş kontrol grubu oluşturmuştur. Çalışmada veri toplama aracı olarak; sosyo-demografik form, Barratt Dürtüselik Ölçegi (BDÖ-11), Anksiyete Duyarlılığı İndeksi (ADI-3) ve Liebowitz Sosyal Fobi Belirtileri Ölçeği (LSFBÖ) kullanılmıştır. Bulgular: Çalışma sonucunda SAB grubunda BDÖ-11 ortalama toplam puanı kontrol grubunun BDÖ-11 ortalama toplam puanından yüksek bulunmuştur $(p<0.001)$. Ayrıca SAB grubunun ortalama toplam ADI-3 puanı kontrol grubunun toplam ADI-3 puan ortalamasından anlamlı derecede daha yüksektir $(p<0.001)$. Uygulanan varyans analizi sonucunda bilişsel ve toplumsal alt ölçek ve toplam ADI-3 puanları ile LSFBÖ puanları arasında pozitif korelasyonlar olduğu bulunmuştur (sırasıyla; $r=0.434, r=0.427$ ve $r=0.351$ ). BDÖ11 alt ölçeklerinden ise yanlızca dikkat dürtüselliği puanı ile LSFBÖ kaçınma alt ölçek puanı arasında negatif korelasyon bulunmuştur $(r=-0.353)$. Sonuç: SAB hastalarının dürtüsellik ve anksiyete duyarlılığı özellikleri sağlıklı bireylerden yüksektir. SAB'da kaçınma belirtilerinin şiddeti, bireylerin anksiyete duyarlılığı ve dikkat dürtüselliği özellikleri ile ilişkilidir.

Anahtar Sözcükler: Anksiyete duyarlılığı, dürtüsellik, Liebowitz Sosyal Fobi Belirtileri Ölçeği, Sosyal Anksiyete Bozukluğu

(Turkish J Clinical Psychiatry 2019;22:7-15)

DOI: $10.5505 / k p d .2018 .47560$ 


\section{INTRODUCTION}

Social Anxiety Disorder (SAD) is a mental disorder characterized by persistent anxiety and avoidance behavior triggered by the presence of a person in a social environment (1). SAD is often associated with decreased functionality and quality of life $(1,2)$. While $92 \%$ of the SAD patients reported having decreased occupational functioning, $85 \%$ of the SAD patients also reported having reduced academic performance (2).

In the SAD development process there exist etiological factors via genetic susceptibility, environmental conditions, individual experiences, and the complex interaction of temperament and character traits (1). Studies on the neurobiology of social anxiety have demonstrated that there is an "alarm system" that affects the prefrontal area, between the amygdala and the hippocampus in the brain (3). Some neuroimaging studies have suggested that the level of the perception of social events as threatening may change depending on the activation in some individuals of this alarm system $(3,4)$. Anxiety sensitivity is known as one of the crucial factors related to this alarm system's activation.

Anxiety sensitivity was first described by Reiss and McNally as "frightening from fear" (5). Anxiety sensitivity is a cognitive process that is considered to be important in the etiology and course of anxiety disorders by providing cognitive constructs of anxiety symptoms (6). Individuals who have higher anxiety sensitivity experienced anxiety symptoms more intensely and more unattainable than others. Studies on the anxiety sensitivity properties of anxiety disorders have shown that different dimensions of anxiety sensitivity are associated with different types of anxiety disorders (6-12). For instance, Rodriguez et al. found that relationships exist between panic disorder and physical dimension, SAD and social dimension, and Generalized Anxiety Disorder (GAD) and cognitive dimension (12).

Impulsivity is another clinical feature, which arouses interest by researchers in several mental disorders. Past research has shown that most of the psychiatric disorders including anxiety disorders, mood disorders, and Attention Deficit and Hyperactivity Disorder (ADHD) may have some impulsivity characteristics, which make treatment and progress of the disorders poorer than those, which do not have impulsivity characteristics (1315). Some studies in the literature also have shown that some subgroups of patients with SAD can display impulsive behaviors instead of the avoidance behaviors that we often expect to observe in patients with SAD (16-18). Kashdan et al. examined the behavior patterns and socio-demographic characteristics of a sample of 1,832 individuals in their study and, found that $79 \%$ of the SAD samples exhibited typical behavioral patterns such as behavioral inhibition and submission, whereas $21 \%$ of displayed more anger and impulsivity characteristics than individuals with typical behaviors (16).

Examining impulsivity and anxiety sensitivity characteristics of patients with SAD can lead the way to administer treatment better for clinicians. Several studies in the literature proposed that different levels of impulsivity and anxiety sensitivity also might have affected the severity of SAD (6-12, 16-18). Interestingly the results of some of the studies related SAD and impulsivity suggest that impulsivity may have an indirect effect in relation to the severity of disorder symptoms, as well as other individual predisposing factors such as personality traits or anxiety sensitivity (16-18). It seems that impulsivity and anxiety sensitivity have a complex function in SAD. However, according to our knowledge, there is no study in the literature that examined the relationships between these two characteristics and severity of SAD concurrently $(6-12,16-18)$. Thus, the aim of this study is to investigate impulsivity and anxiety sensitivity characteristics in SAD patients and to investigate the relationships between these characteristics and the severity of SAD symptoms. The research questions that have been addressed in this study are as follows:

-Is there a significant difference between patients with SAD and healthy controls based on their impulsivity and anxiety sensitivity characteristics?

-Is there a significant relationship between severity of SAD and impulsivity or anxiety sensitivity levels 
of SAD patients?

\section{METHOD}

\section{Participants}

The sample of this study consisted of outpatients with SAD $(n=42)$ who applied to the psychiatry clinic of a university hospital during a one-year period, in addition to healthy individuals $(\mathrm{n}=51)$ who did not receive any psychiatric diagnosis who thus served as the control group. These individuals in the SAD group were selected from outpatients who had not been diagnosed with any other psychiatric comorbidities after a clinical interview based on the American Psychiatric Association's Diagnostic and Statistical Manual of Mental Disorder fifth edition (DSM-5) criteria (19). Individuals who have any other comorbid mental disorder except SAD or any personality disorders according to DSM-5 and who were receiving any psychotropic treatment were excluded from this study. Additionally, we administered all measurements to participants in the SAD group during the first clinical interview before they began to receive any treatment for SAD. Informed consent was obtained from all of the participants in the present study and researchers followed essential ethical rules. An appropriate permission (Decision number:2015/73) was received from the Clinical Research Ethics Committee of the university on 14/12/2015.

\section{Measurements}

The data collection tools of this study were the socio-demographic form, the Barratt Impulsivity Scale (BIS-11), and the Anxiety Sensitivity Inventory (ASI-3) $(9,14)$. Only the Liebowitz Social Anxiety Symptom Inventory (LSAS) was administered to participants just in the SAD group $(20,21)$.

The BIS-11 consists of 30 questions answered on the basis of a self-report. The BIS-11 has three subscales including attention impulsivity (cognitive irregularity and rapid decision making), motor impulsivity (impatience, sudden and unplanned mobility), and non-planning impulsivity (not ma- king any plan due to focus on the present time) (14). To evaluate the BIS-11, four different scores are obtained including total, non-planning, attention, and motor impulsivity scores. The higher the total BIS-11 score means, the higher the impulsivity of the patient (14). The validity and reliability study of BIS-11 in Turkish was confirmed by Güleç et al. (22).

The ASI-3 is the latest version of the ASI and was developed by Taylor et al. (9). Mantar et al. confirmed the validity and reliability of the Turkish version of the scale (6). The ASI-3 consists of 18 items based on a self-report. The scale provides three separate sub-scores (physical, social and cognitive dimensions) and total ASI-3 scores $(6,9)$

The LSAS is a measurement which is used to determine the severity of SAD and it consists of 24 items in two subsections, which are anxiety and avoidance subsections $(20,21)$. The validity and reliability study of the Turkish version of the scale was made by Soykan et al. (23).

\section{Statistical Analyses}

Statistical analyses were carried out in the SPSS (Version 18) program. While the assumption of normality was examined by the Shapiro Wilk test in continuous quantitative variables, homogeneity of variances was evaluated through the Levene test. For the continuous quantitative variables for which the assumptions hold, independent samples t-test was used to compare the groups in terms of sociodemographic characteristics and clinical scales. On the other hand, for variables for which the assumptions do not hold, Mann Whitney Test was used for group comparisons.

The Pearson and Spearman Correlation tests were applied to examine the relationships between quantitative variables. Relationships between categorical variables were also examined by the Pearson Chi-Square and the Fisher-FreemanHalton tests. In this study, $\mathrm{p}<0.05$ was considered statistically significant. 


\section{RESULTS}

Table 1 presents the socio-demographic characteristics of the participants. Regarding Table 1, there was no statistically significant difference between the groups in terms of their socio-demographic characteristics. During the clinical interview, all the participants in two groups were also questioned in terms of lifetime psychiatric history and there was also no statistically significant difference between the groups in terms of lifetime psychiatric diagnosis $(\mathrm{p}=0.376)$.

Regarding the impulsivity characteristics of groups, the mean BIS-11 total score $( \pm \mathrm{SD})$ was $59.9 \pm 9.0$ in the SAD group while it was $53.5 \pm 8.2$ in the control group ( $\mathrm{p}<0.001)$. There was no statistically significant difference between groups in terms of subscores of the BIS-11 (Table-2). Regarding the relationship between the BIS-11 and the LSAS scores, it was found that there was a negative correlation between the attention impulsivity score and the LSAS avoidance subscale score $(\mathrm{r}=-0.353$, $\mathrm{p}=0.022)($ Table 3$)$.

When the groups were compared according to the total ASI-3 mean score, the mean ASI-3 total score of the SAD group was found to be significantly higher than the mean ASI-3 total score of the control group $(\mathrm{p}<0.001)$. When the groups were examined in terms of the ASI-3 subscale scores, the mean scores of the physical, social and cognitive ASI-3 subscales in the SAD group were also significantly higher than the control group's subscales scores $(\mathrm{p}<0.001, \mathrm{p}<0.001$ and $\mathrm{p}<0.001$, respectively) (Table 2).

Regarding the relationships between the ASI-3 and the LSAS scores, the cognitive dimension, the social dimension, and the total scores of ASI-3 were found to be positively correlated with the all LSAS scores (Table 3).

In the SAD group, no statistically significant relationship was found between the BIS-11 total and the subscale scores and the ASI-3 total and the subscale scores (Table 4).

\section{DISCUSSION}

In this study, the impulsivity and anxiety sensitivity characteristics of SAD patients were compared

Table 1: Socio-demographic characteristics of the groups

\begin{tabular}{|c|c|c|c|c|}
\hline & & $\begin{array}{c}\text { Social Anxiety } \\
\text { Disorder Group } \\
\text { n }(\%)\end{array}$ & $\begin{array}{c}\text { Control Group } \\
\mathrm{n}(\%)\end{array}$ & $\mathrm{p}$ \\
\hline \multirow{2}{*}{ Gender $^{* *}$} & Male & $24(57.1)$ & $30(58.8)$ & 0.170 \\
\hline & Female & $18(42.9)$ & $21(41.2)$ & \\
\hline \multirow{2}{*}{ Marital status $^{* *}$} & Married & $8(19.0)$ & $13(25.4)$ & 0.084 \\
\hline & Single & $34(81.0)$ & $38(74.6)$ & \\
\hline \multirow{5}{*}{ Occupation $^{* * *}$} & Public servant & $4(9.5)$ & $7(13.6)$ & \multirow{5}{*}{0.011} \\
\hline & Worker & $4(9.5)$ & $9(17.6)$ & \\
\hline & Student & $26(61.9)$ & $25(48.7)$ & \\
\hline & Housewife & $2(4.8)$ & $2(3.9)$ & \\
\hline & Other* & $6(14.3)$ & $7(13.6)$ & \\
\hline \multirow{2}{*}{ Residence $^{* * *}$} & Urban & $35(83.3)$ & $47(92.8)$ & \multirow[t]{2}{*}{0.054} \\
\hline & Rural & $7(16.7)$ & $4(7.2)$ & \\
\hline \multirow{3}{*}{ Monthly income perception ${ }^{* * *}$} & Not good & $7(16.7)$ & $14(27.5)$ & \multirow[t]{3}{*}{0.079} \\
\hline & Medium & $28(66.7)$ & $35(68.6)$ & \\
\hline & Good & $7(16.7)$ & $2(3.9)$ & \\
\hline Age (years) ${ }^{a, b}$ & & $21.0(18-41)$ & $22.0(19-42)$ & 0.872 \\
\hline Education Level (years) ${ }^{a, b}$ & & $14.0(5-22)$ & $16.0(2-19)$ & 0.285 \\
\hline Mother Education (years) ${ }^{\mathrm{a}, \mathrm{b}}$ & & $5.0(0-16)$ & $5.0(0-16)$ & 0.708 \\
\hline Father Education (years) ${ }^{\mathrm{a}, \mathrm{b}}$ & & $8.0(0-18)$ & $11.0(0-16)$ & 0.090 \\
\hline Number of Siblings $\mathrm{a}, \mathrm{b}$ & & $3.0(1-7)$ & $3.0(0-12)$ & 0.700 \\
\hline
\end{tabular}

*Unemployed, farmer, retired, worker, craftsmen, **Pearson Chi-Square test ***Fisher-Freeman-Halton test, a:Mann Whitney Test, b: Median (Minimum-Maximum). 
The relationships among impulsivity, anxiety sensitivity characteristics, and severity of social anxiety disorder

Table 2: The comparison of the BIS -11 and the ASI -3 scores of groups

\begin{tabular}{lccccc}
\hline & \multicolumn{2}{c}{$\begin{array}{c}\text { Social Anxiety Disorder } \\
\text { group }\end{array}$} & \multirow{2}{*}{ Control group } & \\
\cline { 2 - 5 } & Mean \pm SD & Min-Max & Mean \pm SD & Min-Max & \\
\hline Motor Impulsivity $^{\mathrm{a}, \mathrm{c}}$ & $8.6 \pm 2.8$ & $3.0-16.0$ & $7.6 \pm 2.3$ & $4.0-13.0$ & 0.124 \\
\hline Attentional Impulsivity $^{\mathrm{a}, \mathrm{c}}$ & $8.8 \pm 2.4$ & $5.0-14.0$ & $8.2 \pm 2.4$ & $5.0-17.0$ & 0.163 \\
\hline Non-planning Impulsivity $^{\mathrm{a}, \mathrm{c}}$ & $10.4 \pm 23$ & $5.0-15.0$ & $9.7 \pm 2.8$ & $5.0-19.0$ & 0.121 \\
\hline Total BIS-11 score $^{\mathrm{a}, \mathrm{c}}$ & $59.9 \pm 9.0$ & $42.0-80.0$ & $53.5 \pm 8.2$ & $39.0-73.0$ & $\mathbf{0 . 0 0 1}$ \\
\hline Physical concerns $^{\mathrm{b}, \mathrm{c}}$ & $10.5 \pm 62$ & $0.0-22.0$ & $5.1 \pm 5.6$ & $0.0-24.0$ & $\mathbf{0 . 0 0 1}$ \\
\hline Social Concerns $^{\mathrm{b}, \mathrm{c}}$ & $15.5 \pm 51$ & $4.0-24.0$ & $6.0 \pm 5.3$ & $0.0-20.0$ & $\mathbf{0 . 0 0 1}$ \\
\hline Cognitive concerns $^{\mathrm{b}, \mathrm{c}}$ & $10.2 \pm 58$ & $0.0-23.0$ & $3.5 \pm 4.4$ & $0.0-20.0$ & $\mathbf{0 . 0 0 1}$ \\
\hline Total ASI-3 score $^{\mathrm{c}}$ & $36.2 \pm 13.8$ & $10.0-63.0$ & $14.6 \pm 14.7$ & $0.0-69.0$ & $\mathbf{0 . 0 0 1}$ \\
\hline
\end{tabular}

ASI-3: Anxiety Sensitivity Index -3, BIS-11: Barratt Impulsivity Scale -11, SD: Standard Deviation, Min-Max: Minimum-Maximum, a: BIS-11 sub-scores, b: Dimension scores of ASI -3, c: independent samples $\mathrm{t}$-test, significance at $\mathrm{p}<0.05$.

with those of the healthy controls, and the relationships between these features and the severity of SAD symptoms were examined.

Comparing the BIS-11 scores of the groups the mean total BIS-11 scores of the SAD group were found to be significantly higher than the mean total BIS-11 scores of the control group. Several studies in the literature suggest that some subgroups of patients with SAD have higher impulsivity characteristics than others (24-27). Del Carlo et al. examined the characteristics of impulsivity and additional psychiatric disorders in patients with anxiety disorders and found that the impulsivity characteristics of the anxiety disorders (Agoraphobia, Panic Disorder, and SAD) were higher than those of healthy controls (24). Moreover, Chamorro et al. have examined participants in a community sample of 34.653 adults based on their impulsivity scores and they divided participants into two groups as "impulsive" and "non-impulsive" groups (27). Then Chamorro et al. compared these two groups based on their psychiatric diagnosis. They have found that $12.1 \%$ of the "impulsive" group had individuals who meet the SAD diagnosis criteria. On the other hand, this rate was $5.9 \%$ in the "non-impulsive" group (27). According to the findings of those studies, impulsivity seems to have a complex relationship with SAD.

The general pattern of behaviors of SAD patients consists of social interaction and avoidance behaviors. When the results of the present study are evaluated with abovementioned studies; it is observed that some SAD patients may exhibit impulsive behaviors for purposes such as refusing,

Table 3: The correlations among the LSAS scores, the ASI -3, and the BIS - 11 scores in SAD group

\begin{tabular}{|c|c|c|c|c|}
\hline & & $\begin{array}{c}\text { LSAS } \\
\text { Anxiety Score }\end{array}$ & $\begin{array}{c}\text { LSAS } \\
\text { Avoidance Score }\end{array}$ & $\begin{array}{c}\text { LSAS } \\
\text { Total Score }\end{array}$ \\
\hline \multirow[t]{2}{*}{ Motor Impulsivity ${ }^{\mathrm{a}, \mathrm{c}}$} & $\mathrm{r}$ & -0.016 & -0.258 & -0.108 \\
\hline & $\mathrm{p}$ & 0.918 & 0.100 & 0.497 \\
\hline \multirow[t]{2}{*}{ Attentional Impulsivity ${ }^{\mathrm{a}, \mathrm{c}}$} & $\mathrm{r}$ & -0.189 & -0.353 & -0.264 \\
\hline & $\mathrm{p}$ & 0.231 & 0.022 & 0.091 \\
\hline \multirow[t]{2}{*}{ Non-planning Impulsivity ${ }^{\mathrm{a}, \mathrm{c}}$} & $\mathrm{r}$ & -0.022 & -0.050 & -0.048 \\
\hline & $\mathrm{p}$ & 0.890 & 0.751 & 0.764 \\
\hline \multirow[t]{2}{*}{ Total Impulsivity $^{c}$} & $\mathrm{r}$ & 0.108 & -0.089 & 0.032 \\
\hline & $\mathrm{p}$ & 0.498 & 0.576 & 0.842 \\
\hline \multirow[t]{2}{*}{ Physical concerns ${ }^{b, c}$} & $\mathrm{r}$ & -0.007 & 0.090 & 0.014 \\
\hline & $\mathrm{p}$ & 0.963 & 0.569 & 0.931 \\
\hline \multirow[t]{2}{*}{ Social concerns ${ }^{b, c}$} & $\mathrm{r}$ & 0.400 & 0.430 & 0.427 \\
\hline & $\mathrm{p}$ & 0.009 & 0.004 & 0.005 \\
\hline \multirow[t]{2}{*}{ Cognitive concerns ${ }^{b, c}$} & $\mathrm{r}$ & 0.419 & 0.412 & 0.434 \\
\hline & $\mathrm{p}$ & 0.006 & 0.007 & 0.004 \\
\hline \multirow[t]{2}{*}{ Total ASI-3 Score ${ }^{\mathrm{c}}$} & $\mathrm{r}$ & 0.326 & 0.375 & 0.351 \\
\hline & $\mathrm{p}$ & 0.035 & 0.015 & 0.023 \\
\hline
\end{tabular}

SAD: Social Anxiety Disorder, LSAS: Liebowitz Social Anxiety Scale ,

ASI-3: Anxiety Sensitivity Index -3, BIS-11: Barratt Impulsivity Scale -11, a: BIS-11 sub-scores,

b: Dimension scores of ASI -3, c: Spearman Correlation test, significant at $\mathrm{p}<0.05$. 
Table 4: The correlations between the ASI -3 and the BIS -11 scores in SAD group

\begin{tabular}{llllll}
\hline & & $\begin{array}{l}\text { Physical } \\
\text { concerns }^{\mathrm{b}}\end{array}$ & $\begin{array}{l}\text { Social } \\
\text { concerns }^{\mathrm{b}}\end{array}$ & $\begin{array}{l}\text { Cognitive } \\
\text { concerns }^{\mathrm{b}}\end{array}$ & $\begin{array}{l}\text { Total ASI-3 } \\
\text { Score }\end{array}$ \\
\hline Motor Impulsivity & $\mathrm{r}$ & 0.120 & -0.130 & 0.164 & 0.076 \\
\cline { 2 - 6 } & $\mathrm{p}$ & 0.451 & 0.413 & 0.298 & 0.633 \\
\hline \multirow{2}{*}{ Attentional Impulsivity } & $\mathrm{a}, \mathrm{c}$ & 0.150 & -0.095 & 0.114 & 0.081 \\
\cline { 2 - 6 } & $\mathrm{p}$ & 0.342 & 0.552 & 0.471 & 0.608 \\
\hline Non-planning Impulsivity $^{\mathrm{a}, \mathrm{c}}$ & $\mathrm{r}$ & -0.036 & -0.237 & 0.048 & -0.083 \\
\cline { 2 - 6 } & $\mathrm{p}$ & 0.822 & 0.131 & 0.764 & 0.601 \\
\hline Total Impulsivity $^{\mathrm{c}}$ & $\mathrm{r}$ & 0.092 & -0.135 & 0.300 & 0.119 \\
\cline { 2 - 6 } & $\mathrm{p}$ & 0.563 & 0.395 & 0.054 & 0.454 \\
\hline
\end{tabular}

SAD: Social Anxiety Disorder, ASI-3: Anxiety Sensitivity Index -3, BIS-11: Barratt Impulsivity

Scale-11, a: BIS-11 sub-scores, b: Dimension scores of ASI -3, c: Spearman Correlation test, significant at $\mathrm{p}<0.05$.

rejecting, criticizing, or hurting before being criticized or rejected. In this way, an individual may have an opportunity to protect his/her social status and gain acceptance instead of being rejected. This impulsive way can also provide him/her a solution for coping with his/her anxiety in a quick way. On the other hand, another point of view about the subject is that; people who have impulsive, unplanned, and sudden behaviors are more likely to develop SAD because of the negative consequences they frequently face. A more robust examination of this causal relationship may be possible in future studies with larger samples and longer patient follow-ups. However, the findings of the present study support the current literature, which suggests that SAD is an anxiety disorder, which might have impulsivity characteristics (24-27).

Impulsivity can also affect symptom severity and treatment outcomes of patients with any kind of mental disorders $(16-18,26)$. Therefore, one main purpose of the present study was to investigate the relationship between impulsivity and symptom severity levels of patients with SAD. Regarding the findings of this investigation, we found a negative correlation only between the attention impulsivity score of the SAD patients and the LSAS avoidance sub-scale score. Attention impulsivity is defined as having difficulty paying attention, being indecisive or displaying an intolerance of cognitive complexity (14). Therefore, this result showed that among patients with SAD, those who have higher attention impulsivity characteristics also have lower avoidance symptom severity than other patients with SAD. This supports the idea that attention impulsivity characteristics might be a predictor for determining patients who can display much more impulsive behaviors than expected avoidance behaviors in SAD (16-18). The alignment of impulsivity characteristics with any mental disorder is important for clinicians in terms of planning optimal treatment and follows up for patients. According to Kashdan and McKnight, impulsive behaviors can be used by SAD patients effectively in reducing short-term anxiety symptoms and preventing rejection from others. However, these behaviors can lead to long-term negative outcomes related to life satisfaction, physical and mental health and total life expectancy (26). In the field of the relationships between impulsivity and treatment outcomes of SAD patients, Erwin et al. examined the participants' depressive symptoms, coping attitudes, cognitive behavioral psychotherapy outcomes, and severity of SAD symptoms (28). Erwin et al. found that participants who had higher impulsive features were less likely to benefit from treatment than others who did not have those features. Considering that the basic practices of cognitive behavioral psychotherapy in SAD include various behavioral interventions, individuals who are impulsive, who make sudden decisions, and who exhibit higher anger behaviors may be less likely to complete such a therapy (29).

Anxiety sensitivity is another clinical feature associated with SAD as well as several anxiety disorders as a susceptibility factor $(8,30-33)$. Recent studies related to anxiety sensitivity in SAD revealed that social anxiety sensitivity was predictive for SAD (8, 30-33). The findings of the present study based on higher levels of social dimension scores of ASI in the SAD group are consistent with the findings reported in the literature $(8,30-33)$. In addition to these studies, we found that not only social dimension but also the cognitive and physical dimension of ASI may determinate the severity of SAD. It is a 
well-known clinical finding that individuals with SAD are highly aware of their physical senses, especially those individuals exposed to physical sensations such as facial flushing, sweating or trembling, which are present during social interactions (34). It is also known that processes such as negative evaluation in the society, negative interpretation of the event by rumination before or after the social interaction are crucial manners in the cognitive structure of SAD. Individuals who are more sensitive to the cognitive manifestations of anxiety also be expected to apply more of these abovementioned negative appraisals.

Although anxiety sensitivity is an individual susceptibility factor for anxiety, several studies have also shown that anxiety sensitivity may be reduced with the help of psychotherapy or pharmacotherapy (35). Therefore determining patients who have higher anxiety sensitivity also crucial for better treatment management of patients with SAD (35). Regarding examination of the relationship between anxiety sensitivity and severity of SAD in the present study, it was found that there was a positive correlation between cognitive and social anxiety sensitivity characteristics, and total ASI-3 scores and all subscale and total scores of LSAS. Additionally, regarding the assessment of the relationships between impulsivity and symptom severity of SAD we found that among the patients with SAD those who have higher attention impulsivity characteristics also have lower avoidance symptom severity than other patients. Therefore, all have the attention impulsivity, cognitive and social anxiety sensitivity characteristics seem to be associated with symptom severity of SAD. When we assess the two main results of our study we can point out that both higher anxiety sensitivity and lower attention impulsivity characteristics can lead to higher symptom severity of SAD related to avoidance.

Regarding examining the relationship between anxiety sensitivity and impulsivity features, there was no significant correlation between anxiety sensitivity and impulsivity characteristics of patients with SAD in the present study. Additionally, to our knowledge, there is no study in the literature that examined the relationship between anxiety sensitivity and impulsivity characteristics of patients with SAD. There were only two studies, which examined the association between anxiety sensitivity and risktaking behavior such as gambling and substance use in nonclinical samples. In the first study, researchers claimed that individuals with high anxiety sensitivity characteristics display significantly less risk-taking than their low counterparts who have less anxiety sensitivity characteristics (36). In the results of the second study showed that adolescents who had higher impulsivity in addition to higher anxiety sensitivity characteristics demonstrated much more maladaptive ways such as substance use for coping with their anxiety (37). Therefore, Comeau et al. claimed that anxiety sensitivity could be a mediator for the relationship between anxiety and impulsivity (37). Although there were significant relationships between symptom severity of SAD and anxiety sensitivity or impulsivity separately, we could not find any association between anxiety sensitivity and impulsivity. These differences between the present study and past research discussed above might be derived from different methods and clinical samples used in those studies. Hence, future studies need to be done in larger clinical samples and with different methods for examining the relationship between impulsivity and anxiety sensitivity.

One of the limitations of the present study is the limited size of the participants. This limitation was derived from our eligibility criterion for participants such as not having any additional psychiatric diagnoses other than SAD. Although SAD is one of the most common mental disorders, patients with SAD are less likely to apply for treatment without additional psychiatric complaints. Another limitation of this study is that data collection tools are based on self-declaration of participants. The last limitation of the present study is that assessing impulsivity only for using inventory without any behavioral or cognitive tasks as mentioned before.

Despite having these limitations, the present study contributes to the limited literature on the relationships among anxiety sensitivity, impulsivity, and SAD. Specifically, findings of the present study imply that individuals with higher anxiety sensitivity and lower attention impulsivity tend to have higher avoidance symptom severity than others. Determining the anxiety sensitivity and impulsivity characteristics of patients with SAD can provide a 
guide to managing appropriate treatment model for clinicians.

\section{CONCLUSION}

In conclusion, patients with SAD may have more impulsive characteristics than healthy individuals. The extensive sampled studies are needed to understand whether these individuals use impulsivity for coping with their anxiety and whether SAD is a result of their failures due to their impulsive behaviors in social interaction.

Additionally, anxiety sensitivity characteristics of an individual can be used as the preliminary factor to predict which individuals are more likely to develop SAD and also to predict symptom severity of present SAD. It is also critical to assess not only the social dimension but also the cognitive and physical dimension of ASI for examining anxiety sensitivity characteristics of patients with SAD. Finally, symptom severity of SAD is associated with both anxiety sensitivity and attention impulsivity characteristics of individuals.

Correspondence address: M.D. Safiye Bahar Olmez, Department Of Psychiatry, Düzce University School Of Medicine, Düzce, Turkey safiyebaharolmez@gmail.com

\section{REFERENCES}

1. Stein MB, Chen CY, Jain S, Jensen KP, He F, Heeringa SG, Kessler RC, Maihofer A, Nock MK, Ripke S, Sun X, Thomas ML, Ursano RJ, Smoller RJ, Gelernter J. Genetic risk variants for social anxiety. Am Jour of Med Gen 2017; 174:120-131.

2. Dilbaz N. Sosyal fobi. Psikiyatri Dünyası 1997; 1:18-24. (Turkish)

3. Tillfors M. Why do some individuals develop social phobia? A review with emphasis on the neurobiological influences. Nord J Psychiatry 2004;58:267-276.

4. Tillfors M, Furmark T, Marteinsdottir I, Fredrikson M. Cerebral blood flow during anticipation of public speaking in social phobia: a PET study. Biol Psychiatry 2004;52:1113-1119.

5. Reiss S, Peterson RA, Gursky DM, McNally RJ. Anxiety sensitivity, anxiety frequency and the prediction of fearfulness. Behav res and therapy 1986;24:1-8.

6. Mantar A, Yemez B, Alkın T. Anksiyete duyarlılığı ve psikiyatrik bozukluklardaki yeri. Turk Psikiyatri Derg 2011;22:187193. (Turkish)

7. Rector NA, Szacun-Shimizu K, Leybman M. Anxiety sensitivity within the anxiety disorders: Disorder-specific sensitivities and depression comorbidity. Behav Res Ther 2007;45:19671975.

8. Naragon-Gainey K. Meta-analysis of the relations of anxiety sensitivity to the depressive and anxiety disorders. Psychol Bull 2010;36:128-138.

9. Taylor S, Zvolensky MJ, Cox BJ Daecon B, Heimberg R, Ledley G, Coles M. Robust dimensions of anxiety sensitivity: development and initial validation of the Anxiety Sensitivity Index-3. Psychol Assess 2007; 9:176.

10. Taylor S. Anxiety sensitivity: Theory, research, and treatment of the fear of anxiety. Routledge 2014, 76-99.

11. McNally RJ. Anxiety sensitivity and panic disorder. Biol Psychiatry 2002;52:938-946.

12. Rodriguez BF, Bruce SE, Pagano ME. Factor structure and stability of the Anxiety Sensitivity Index in a longitudinal study of anxiety disorder patients. Behav Res Ther 2004;42:79-91.

13. Öztürk MO, Uluşahin A Mental Health and Mental Disorders. Eleventh ed., Ankara, Nobel Tip Kitapları, 2013, pp. 462-468. (Turkish)

14. Patton JH, Stanford MS. Factor structure of the Barratt impulsiveness scale. J. Clin. Psychol 1995;51:768-774.

15. Özdemir PG, Selvi Y, Aydın A. Impulsivity and its treatment. Psikiyatride Guncel Yaklasimlar 2012;4:293-314. (Turkish) hibition: an analysis of curiosity and social rank appraisals, approach-avoidance conflicts, and disruptive risk-taking behavior. J Anxiety Disord 2008;22:925-939.

17. Kashdan TB, Hofmann SG. The high?novelty-seeking, impulsive subtype of generalized social anxiety disorder. Depress and Anxiety 2008;25:535-541.

18. Mörtberg E, Tillfors M, Zalk N, Kerr M. An atypical anxious impulsive pattern of social anxiety disorder in an adult clinical population. Scand J Psychol 2014;55:350-356.

19. American Psychiatric Association. Diagnostic and statistical manual of mental disorders. 5th edition. Arlington, VA: American Psychiatric Pub, 2013.

20. Liebowitz MR. Social phobia. Mod Probl Pharmacopsychiatry 1987;22:141-173.

21. Heimberg RG, Horner KJ, Juster HR Safren SA, Brown EJ, Schneier FR, Liebowitz MR. Psychometric properties of the Liebowitz social anxiety scale. Psychol Med 1999;29:199-212.

22. Güleç H, Tamam L, Güleç MY, Turhan M, Karakus G, Zengin M, Standford MS. Psychometric properties of the Turkish version of the Barratt Impulsiveness Scale-11. Bulletin of Clinical Psychopharmacology 2008; 8:251-258. (Turkish)

23. Soykan Ç, Özgüven HD, Gençöz T. Liebowitz social anxiety scale: the Turkish version Psycholog Rep 2003; 9(suppl3):10591069. (Turkish)

24. Del Carlo A, Benvenuti M, Fornaro M, Toni Cristina,
16. Kashdan TB, Elhai JD, Breen WE. Social anxiety and disin- 
Rizzato S, Swann AC, Dell'Osso L, Perugi G. Different measures of impulsivity in patients with anxiety disorders: a case control study. Psychiatry Res 2012;197:231-236.

25. Kachin KE, Newman MG, Pincus AL. An interpersonal problem approach to the division of social phobia subtypes. Behav Ther, 2001;32:479-501.

26. Kashdan TB, McKnight PE. The darker side of social anxiety when aggressive impulsivity prevails over shy inhibition. Curr Dir Psychol Sci 2010; 19:47-50.

27. Chamorro J, Bernardi S, Potenza MN. Impulsivity in the general population: a national study. J Psychiatr Res 2012;46:994-1001.

28. Erwin BA, Heimberg RG, Schneier FR, Liebowitz MR Anger experience and expression in social anxiety disorder: Pretreatment profile and predictors of attrition and response to cognitive-behavioral treatment. Behav Ther 2003;34:331-350.

29. Türkçapar MH. Cognitive Behavioral Therapy. Third ed., Ankara, Hekimler Yayin Birligi, 2017, pp. 40-45. (Turkish)

30. Taylor S, Koch WJ, McNally RJ. How does anxiety sensitivity vary across the anxiety disorders? J Anxiety Disord 1992; 6:249-259

31. Grant DM, Beck JG, Davila J. Does anxiety sensitivity predict symptoms of panic, depression, and social anxiety? Behav Res Ther 2007;45:2247-2755.

32. Zinbarg RE, Brown TA, Barlow DH, Rapee RM. Anxiety sensitivity, panic, and depressed mood: A reanalysis teasing apart the contributions of the two levels in the hierarchical structure of the Anxiety Sensitivity Index. J Abnorm Psychol 2001;110:372-376
33. McWilliams LA, Stewart SH, MacPherson PS. Does the social concerns component of the Anxiety Sensitivity Index belong to the domain of anxiety sensitivity or the domain of negative evaluation sensitivity? Behav Res Ther 2000;38:985-992.

34. Costello CG. Fears and phobias in women: A community study. J Abnorm Psychol 1982; 91:280.

35. Cox BJ, Taylor S, Enns MW. Fear of cognitive dyscontrol in relation to depression symptoms: Comparisons between original and alternative measures of anxiety sensitivity. J Behav Ther Exp Psychiatry 1999;30:301-311.

36. Broman-Fulks, JJ, Urbaniak A, Bondy CL, Toomey KJ. Anxiety sensitivity and risk-taking behavior. Anxiety, Stress, \& Coping 2014; 27:619-632.

37. Comeau N, Stewart SH, Loba P. The relations of trait anxiety, anxiety sensitivity, and sensation seeking to adolescents' motivations for alcohol, cigarette, and marijuana use. J Addict Behav Ther 2001;26:803-825. 